\title{
PENGEMBANGAN SOFTWARE OF HOSPITALITY ACCOUNTING DICTIONARY
}

\author{
Gede Adi Yuniarta \\ Jurusan D3 Akuntansi, Fakultas Ekonomi dan Bisnis \\ Universitas Pendidikan Ganesha, Singaraja, Indonesia \\ Email :gdadi_ak@yahoo.co.id
}

\begin{abstract}
Abstrak
Hospitality Accounting (Akuntansi Perhotelan) merupakan bidang akuntansi terapan di dunia pariwisata. Dilihat dari bidang akuntansi, dunia bisnis pariwisata berbeda dengan dunia usaha lainnya karena merupakan kombinasi antara jasa dan produksi. Sampai dengan saat ini literatur pendukung untuk bidang Hospitality Accounting baik untuk pendidikan maupun untuk para praktisi masih sangat minim, sedangkan kebutuhan akan ketrampilan di bidang ini sangat besar. Hal ini menyebabkan pembelajaran mata kuliah ini menjadi kurang maksimal. Literatur yang ada belum mampu memberikan informasi spesifik mengenai implementasi Akuntansi dalam kondisi riil di dalam usaha perhotelan. Kamus akuntansi perhotelan atau Hospitality Accounting Dictionary merupakan istilah-istilah yang merupakan komponen penting dalam penguasaan Hospitality Accounting. Istilahistilah dalam Hospitality Accounting sangatlah berbeda dengan akuntansi secara umum terlebih lagi saat ini informasi mengenai istilah tersebut belum terkoordinasi dalam satu literatur yang tepat. Tujuan jangka panjang dari penelitian ini adalah untuk menghasilkan literatur dalam bentuk Software of Hospitality Accounting Dictionary yang dapat dimanfaatkan dalam pembelajaran Akuntansi Perhotelan di kelas yang sekaligus juga dapat dimanfaatkan sebagai sumber informasi pemakai baik masyarakat umum maupun praktisi di di dunia perhotelan. Penelitian ini menggunakan model pengembangan four $D$ Models yang terdiri dari 4 tahap pengembangan, yaitu Define, Design, Develop, dan Desseminate. Hasil penelitian di tahun pertama (2013) menghasilkan draf Software of Hospitality Accounting Dictionary. Penelitian di tahun ke dua (2014) menyempurnakan draft menjadi Software of Hospitality Accounting Dictionary yang siap online dan diujicobakan secara luas pada beberapa hotel berbintang di Bali dengan hasil menunjukkan para praktisi akuntansi perhotelan merasa puas dengan produk yang dihasilkan dan layak untuk diimplementasikan.
\end{abstract}

Kata kunci: Software, Hospitality Accounting, Dictionary, pembelajaran, praktisi perhotelan

\begin{abstract}
Accounting for Hospitality is accounting science which applied in the world of tourism. Reviewed from the fields of accounting, business of tourism is different from other business because it is a combination of services and production. Up to now, supporting literature of accounting for hospitality both for education and the practitioners still very low while the demand for skills in this field is very large. This led to learning this course to be less of maximum. The existing literature has not
\end{abstract}


been able to provide specific information on the implementation of Accounting in the real conditions in the hospitality business. Dictionary of accounting for hospitality are terms which is an important component in mastering hospitality accounting. Terms in hospitality accounting is very different from the general accounting moreover current information regarding the terms have not been coordinated in the appropriate literature. The long term goal of this research is to produce literature in the form of software of hospitality accounting dictionary which can be used in learning hospitality accounting in the class and also can be used as a source of consumer information both public and practitioners in the world of hospitality. This study uses development model of four D Models that consists of 4 stages of development such as Define, Design, Develop, and Disseminate. The results of research in 2013 has produce a draft of software of hospitality accounting dictionary. The research in the second year (2014) perfect the draft to be Software of Hospitality Accounting Dictionary which are ready online and tested extensively on several star hotels in Bali which the results showed that hospitality accounting practitioners are satisfied with the resulting product.

Keywords: Software, Hospitality Accounting, Dictionary, learning, hospitality practitioners

\section{PENDAHULUAN}

Hospitality Accounting (Akuntansi
$\begin{aligned} & \text { Acrupakan bidang } \\ & \text { merhotelan) }\end{aligned}$
akuntansi terapan di dunia pariwisata.
Penerapan akuntansi perhotelan
berbeda dengan dunia usaha lainnya karena merupakan kombinasi antara jasa dan produksi. Hotel merupakan usaha jasa pelayanan atau disebut "hospitality service" yang seluruh atau sebagian bangunan digunakan untuk pelayanan kamar, makanan, minuman serta rekreasi yang dikelola dengan tujuan komersial (Diatmika dan Adi, 2010). Untuk itu hotel sebagai penjual jasa harus dapat menyediakan tiga hal yaitu; fasilitas yang memadai, sumberdaya manusia yang terampil untuk melayani dan pengelolaan yang profesional. Untuk memenuhi hal tersebut dengan sendirinya hotel membutuhkan biaya yang cukup besar dan mahal, baik biaya untuk menyediakan fasilitas maupun biaya untuk pengadaan sumber daya manusia yang melayani berupa gaji yang memadai dan pelatihan-pelatihan yang lebih baik. Semua perhitungan untuk pembiayaan seperti gaji pegawai, transportasi, pemasaran, pembelian semua barang kebutuhan, sampai sekecil-kecilnya harus diperhitungkan secara cermat. Dan untuk mendapatkan data yang cukup akurat serta mengurusi dan mendata keluar masuknya uang maka diperusahaan hotel diperlukan satu departemen khusus yang biasa disebut Accounting Departement atau Departemen Akuntansi. Akuntansi Perhotelan merupakan syarat mutlak yang harus dikuasai oleh pegawai yang bekerja di Accounting Departement (Diatmika dan Adi, 2010).

Akuntansi Perhotelan merupakan mata kuliah akuntansi terapan yang mengkaji perlakuan akuntansi pada sektor perhotelan. Dalam mata kuliah ini materi pembelajaran difokuskan pada sistem akuntasi perhotelan dengan salah satu komponen utamanya adalah 
kamus untuk akuntansi perhotelan (Hospitality Accounting Dictionary). Kamus akuntansi perhotelan dalam akuntansi perhotelan merupakan istilahistilah yang merupakan komponen penting dalam penguasaan Akuntansi Perhotelan. Namun saat ini dalam proses pembelajaran mata kuliah Akuntansi Perhotelan terbentur dengan kendala sangat minimnya literatur pendukung terutama literatur yang mampu memberikan informasi spesifik mengenai implementasi Akuntansi dalam kondisi riil di dalam usaha perhotelan termasuk litaratur dalam bentuk kamus akuntansi perhotelan yang belum terkoordinasi dalam satu literatur yang tepat.

Pengguna tenaga profesional di bidang akuntansi menuntut kompetensi minimal yang harus di kuasai oleh pekerjanya. Kompetensi tersebut dikelompokkan dalam dua dimensi yaitu kompetensi bidang akuntansi dan kompetensi lainnya yang berhubungan dengan hubungan personal di dunia kerja, (Adi Yuniarta, 2009). Kompetensi bidang akuntansi merupakan penguasaan akuntansi secara substansial, sedangkan kompetensi lainnya yang paling menonjol adalah kemampuan mengkombinasikan ilmu akuntansi dengan perkembangan teknologi. Untuk dapat mencapai kompetensi ini maka pembelajaran yang dilakukan harus juga mengkombinasikan substansi keilmuan akuntansi dengan perkembangan teknologi. Pemanfaatan teknologi dalam pembelajaran menunjukkan pengaruh yang signifikan dalam meningkatkan kualitas pembelajaran. Hal ini dibuktikan dengan penggunaan media pembelajaran kasus akuntansi berpendekatan $\mathrm{PBL}$ dengan $M Y O B$ Accounting terbukti dapat meningkatkan aktivitas belajar mahasiswa dan hasil belajar, (Adi Yuniarta, 2008). Penelitian lain juga membuktikan bahwa hasil pengembangan Program komputer akuntansi terpadu dapat dimanfaatkan untuk dapat meningkatan profesionalisme dosen dalam proses belajar mengajar, (adi Yuniarta, 2007).

Penelitian yang telah dilakukan sebelumnya oleh Diatmika dan Adi Yuniarta pada tahun 2011 telah menghasikan kamus Chart of Accounts Akuntansi Perhotelan yang sudah berISBN dan diujicobakan dalam proses pembelajaran dan terbukti perserta didik merasa sangat puas dengan pemanfaat kamus dalam pembelajaran mata kuliah akuntansi perhotelan. Pemanfaatan kamus oleh para praktisi akuntansi perhotelan juga menunjukkan sangat layak dengan keberadaan kamus ini dan yang terakhir terkait dengan hasil deseminasi juga menunjukkan hasil yang sangat layak. Bahkan saat ini kamus Chart of Accounts Akuntansi Perhotelan sudah digunakan untuk pembelajaran dan juga oleh praktisi di 17 hotel berbintang di Bali. Namun masih terdapat kelemahan- kelemahan dari kamus ini dan kelemahan yang paling signifikan adalah tidak mengakomodasi perkembangan teknologi (Diatmika dan Adi, 2011).

Berdasarkan hasil penelitian sebelumnya masih menunjukkan kekuranglengkapan dalam hal isi terkait dengan perkiraan yang sfesifik ditambah lagi dengan kelemahan yang paling signifikan adalah tidak mengakomodasi perkembangan teknologi mengharuskan adanya pengembangan yang lebih terfokus lagi terutama 
mengkombinasikan perkembangan teknologi dengan substansi akuntansi perhotelan. Perkembangan teknologi informasi yang demikian pesat menyebabkan dipandang perlu terwujudnya suatu kamus akuntansi perhotelan yang dapat mengakomodasi perkembangan teknologi.

Implementasi akuntansi di dunia perhotelan dapat dilihat dari dua sudut yaitu : (1) dari sudut pemakai akuntansi perhotelan merupakan suatu disiplin yang menyediakan informasi yang diperlukan untuk melaksanakan kegiatan secara efisien dan mengevaluasi kegiatan- kegiatan perhotelan yang digunakan untuk membuat perencanaan yang efektif, pengawasan, pengambilan keputusan oleh manajemen dan pertanggungjawaban pengelolaan pada investor, kreditur, badan pemerintah, donatur dan sebagainya, (2) dari sudut proses kegiatan: akuntansi perhotelan merupakan suatu proses pencatatan, penggolongan, peringkasan, pelaporan dan penganalisaan data keuangan suatu organisasi perhotelan. Sedangkan yang menggunakan informasi akuntansi adalah; (1) Manajemen dalam hal ini manajemen hotel menggunakan laporan keuangan untuk menyusun program kerja, mengevaluasi kemajuan yang dicapai dalam mencapai tujuan, melakukan tindakan tindakan koreksi yang diperlukan dan sebagai salah satu sarana pertanggungjawaban,

Karyawan Hotel memerlukan informasi keuangan untuk mengetahui keadaan keuangan hotel, mengetahui kinerja organisasi serta untuk menyikapi pertanggungjawaban pengelola. (3) Pemilik Hotel memerlukan informasi keuangan untuk mengetahui kinerja hotel, digunakan sebagai dasar perencanaan investasi berikutnya, (4) Pemerintah memerlukan informasi keuangan terutama untuk control dan kebijakan berikutnya, (5) Calon debitur dan debitur memerlukan informasi keuangan sebagai dasar pertimbangan pemberian kredit dan mengevaluasi kredit yang sudah diberikan, dan (6) masyarakat umum lainnya yang dapat digunakan untuk kepentingan penelitian, komparatif dan perkembangan perekonomian (Haryono Jusuf, 2011)

Untuk dapat mencapai tujuan akuntansi perhotelan diperlukan suatu pemahaman Sistem Akuntansi Perhotelan. Sistem akuntansi perhotelan merupakan organisasi formulir, catatan, dan laporan yang dikoordinasi sedemikian rupa untuk menyediakan informasi keuangan yang dibutuhkan oleh manajemen guna memudahkaan pengelolaan hotel. Komponen utama dari sistem akuntansi perhotelan adalah istilah- istilah dari akuntansi perhotelan yang saling terkait dalam pembentukan suatu sistem akuntansi perhotelan. Untuk dapat memahami akuntansi perhotelan maka literature pendukung berupa kamus istilah akuntansi perhotelan sangatlah diperlukan. Terlebih lagi apabila kamus tersebut sudah tertuang dalam bentuk software yang mengakomodasi perkembangan teknologi informasi dan komputer seperti software "Hospitality Accounting Dictionary". Nampak jelas bahwa untuk dapat memahami akuntansi perhotelan haruslah terlebih dahulu memahami istilah-istilah akuntansi perhotelan. Pemahaman akuntansi perhotelan dapat dilihat; (1) dari sisi proses pembelajaran di kelas harus dapat memberikan informasi yang maksimal akan kondisi 
akuntansi riil di dunia perhotelan jelas harus didukung oleh literature yang lengkap dan menunjukkan kondisi atau implementasi riil di dunia perhotelan, (2) dari sisi pelaksanaan di dunia kerja para praktisi perhotelan juga memerlukan pemahaman dan informasi yang relevan dalam menyusun laporan keuangan sehingga juga sangat memerlukan litaratur yang dapat memberikan informasi yang tepat dan aplikatif. Dengan ketersediaan litaratur yang tepat dan menggambar kondisi riil di dunia perhotelan maka diharapkan proses pembelajaran yang menghasilkan pemahaman baik bagi siswa maupun kalangan praktisi dapat dicapai dengan hasil yang maksimal.

Perkembangan

teknologi

memberikan pengaruh yang besar diberbagai bidang, tidak terkucuali di bidang akuntansi. Pemanfaatan teknologi tidak saja dalam hal pemanfaatan praktis di dunia kerja tetapi juga dalam bidang pengajaran. Menurut Adi Yuniarta (2007) hasil pengembangan Program komputer akuntansi terpadu dapat dimanfaatkan untuk meningkatkan kualitas pembelajaran terutama sebagai wadah pembelajaran, alat bantu dalam interaksi pembelajaran, sumber belajar dan dapat meningkatan profesionalisme dosen dalam proses belajar mengajar. Perkembangan teknologi ini juga pasti merambah dunia perhotelan. Tidak dapat dipungkiri bisnis hotel mutlak menggunakan perkembangan teknologi termasuk diantaranya yang terkena imbas adalah akuntansi perhotelan. Perkembangan pesat teknologi komputer dan informasi mengharuskan akuntansi perhotelan dapat mengkombinasikan perkembangan tersebut dengan substansi akuntansi. Adanya perkembangan teknologi informasi yang demikian pesat maka dipandang perlu terwujudnya suatu kamus akuntansi perhotelan yang dapat mengakomodasi perkembangan teknologi informasi tersebut. Berdasarkan uraian tersebut maka terwujudnya Software of Hospitality Accounting Dictionary dianggap penting sebagai bahan literatur dalam pembelajaran akuntansi perhotelan yang mengakomodasi perkembangan teknologi informasi.

Tujuan dari penelitian ini adalah terwujudnya Software of Hospitality Accounting Dictionary yang dapat digunakan sebagai literatur dalam pembelajaran mata Kuliah Akuntansi Perhotelan di kelas yang sekaligus juga dapat dimanfaatkan sebagai sumber informasi pemakai baik masyarakat umum maupun praktisi di di dunia perhotelan. Produk penelitian ini akan mengakomodasi aspek-aspek; kondisi riil kebutuhan dalam mata kuliah Akuntansi Perhotelan, (2) kelengkapan informasi yang tersaji, (3) validitas baik dari akademisi maupun praktisi perhotelan, (4) kepraktisan dan keefektifan untuk penggunaan dalam proses belajar mengajar di kelas, dan (5) kepraktisan dan keefektifan dalam penggunaan di dunia kerja. Tujuan khusus penelitian ini adalah; (1) untuk membuktikan bahwa produk yang dihasilkan dapat meningkatkan kualitas pembelajaran mata kuliah Akuntansi Perhotelan yang teruji dengan peningkatan aktivitas, hasil dan sumber belajar, (2) untuk mengetahui persepsi pemakai terutama membuktikan kelayakan produk bagi masyarakat umum khususnya praktisi perhotelan. 


\section{METODE PENELITIAN}

Dalam penelitian ini digunakan model pengembangan perangkat pembelajaran four $D$ Models (model 4D). Model ini terdiri dari 4 tahapan pengembangan, yaitu : Define, Design, Development dan Desseminate (Arnyana, 2006). Untuk penelitian yang sudah terleksana di Tahun I (2013) dilakukan dalam dua tahapan yaitu : Tahap Define (Pendefinisian) pelaksanaan tahapan ini memiliki tujuan menetapkan dan mendefinisikan syaratsyarat Software of Hospitality Accounting Dictionary. Tahap kedua adalah Tahap Design (Perancangan) pada tahapan ini dilakukan perancangan prototipe software of Hospitality Accounting Dictionary. Dalam tahapan ini lakukan penyusunan sistematika, pemilihan media dan pemilihan format. Pemilihan format dilakukan dengan mengkaji format-format kamus lain yang telah ada dan disesuaikan dengan kebutuhan sesuai dengan tujuan yang ingin dicapai yaitu dapat digunakan secara maksimal oleh pengguna software. Produk akhir tahapan ini adalah draft software of Hospitality Accounting Dictionary.

Pengumpulan bahan kamus dilakukan pada beberapa hotel berbintang di Bali Hotel berbintang di Bali. Untuk uji coba kamus dilakukan di Universitas Pendidikan Ganesha, sedangkan untuk uji kerlayakan implementasi di duni usaha dilakukan di hotel berbintang di Bali. Yang menjadi subjek dalam penelitian ini adalah dosen, mahasiswa yang memprogram mata kuliah Akuntansi Perhotelan, Praktisi Perhotelan di Beberapa Hotel berbintang di Bali. Sementara objek penelitian adalah pengembangan software of Hospitality Accounting Dictionary. Instrumen pengumpulan data yang digunakan terdiri dari beberapa instrument yaitu : (1) pedoman Observasi, (2) kuisioner, (3) pedoman wawancara, (4) studi dokumentasi.Teknik analisis data yang digunakan dalam penelitian ini adalah analisis deskriptif dengan penggunaan data-data kuantitatif yang merupakan keberhasilan dari penerapan yang dilakukan dengan pengungkapan deskriptif melalui perbandingan nilai ratarata, simpangan baku dan persentase yang terjadi. Hasil dari analisa data kemudian akan didiskripsikan disertai dukungan data kuantitatif dan argumentasi kualitatif.

\section{HASIL DAN PEMBAHASAN}

Gambaran umum hasil penelitian di tahun pertama (2013) dapat diuraikan sebagai berikut : penelitian diawali dengan tahap Define (Pendefinisian ) yang dilakukan melalui dua kegiatan yaitu studi pustaka terhadap berbagai literatur akuntansi perhotelan dan studi lapangan berupa studi terhadap berbagai jenis laporan keuangan perhotelan. Hasil studi pustaka memberikan hasil gambaran sistem secara menyeluruh terhadap akuntansi perhotelan dengan tingkat kompleksitas yang tinggi. Hasil ini memberikan masukan terhadap rancangan literatur yang tepat berupa kamus yang dapat memberikan gambaran yang lebih sederhana dari kompleksitas akuntansi perhotelan yang ada. Studi terhadap berbagai laporan keuangan memberikan hasil gambaran umum mengenai berbagai kelompok perkiraan dalam laporan keuangan. Hasil studi juga menunjukkan terjadi pengelompokan 
berbagai perkiraan sesuai dengan fungsi dan departemen yang ada di hotel. Hasil temuan berbagai kajian ini memberikan gambaran yang dapat menjadi masukan dalam penyusunan kamus terutama dalam hal pembagian pengelompokan perkiraan sesuai dengan deskripsi perkiraan / akun dan juga sesuai dengan departemen yang ada di hotel.

Kegiatan penelitian berikutnya adalah pengumpulan data laporan keuangan riil yang ada di hotel berbintang di Bali. Hotel berbintang dipilih karena laporan keuangan hotel berbintang yang paling kompleks dan lengkap. Survei awal terhadap hotel berbintang menghasilkan bahwa tidak semua hotel berbintang bersedia memberikan laporan keuangannya. Dari 27 hotel berbintang yang disurvei akhirnya ada 13 hotel berbintang yang bersedia memberikan laporan keuangan lengkap mereka. Sebaran lokasi hotel tersebut adalah 3 hotel di Kuta, 5 Hotel di wilayah Sanur, 3 hotel di wilayah Nusa Dua dan 1 Hotel di wilayah Candi Dasa. Pengumpulan laporan keuangan ini memerlukan waktu yang cukup lama, namun akhirnya data dapat dikumpulkan secara lengkap.

Kegiatan berikutnya adalah menyusun draft kamus secara manual. Penyusunan kamus ini dikelompokkan menjadi 3 kelompok yaitu bagan perkiraan/akun, diskripsi/keterangan dan departemen. Dalam kegiatan ini dhasilkan 1338 perkiraan /akun untuk akuntansi perhotelan dengan deskripsi akun juga sebanyak 1338. Sedangkan departemen yang ada sebanyak 8 departemen yang terdiri atas departemen: adminitration and general, food and beverage, human resources, maketing, other operation dept, POMEC, Rooms dan Telephone and telex. Total jumlah halaman mdraft kamus secara manual adalah sebanyak 168 halaman.

Setelah bahan kamus manual terpenuhi maka kegiatan berikutnya adalah memasuki tahapan desain. Kegiatan Pada tahapan ini dilakukan perancangan prototipe software of Hospitality Accounting Dictionary. Dalam tahapan ini lakukan penyusunan sistematika, pemilihan media dan pemilihan format. Pemilihan format dilakukan dengan mengkaji formatformat kamus lain yang telah ada dan disesuaikan dengan kebutuhan sesuai dengan tujuan yang ingin dicapai yaitu dapat digunakan secara maksimal oleh pengguna software. Software dibuat dengan bahasa pemrograman PHP dengan aplikasi macromedia.

Draft software kamus dirancang dalam 4 jendela. Jendela pertama merupakan substansi kamus dimana kamus berfungsi sebagai mesin pencarian tiga dimensi kamus yaitu bisa berupa account, Description dan Departement. Account berisikan berbagai perkiraan akuntansi perhotelan. Pengguna dapat mengklik bagian ini untuk mencari berbagai akun akuntansi perhotelan yang ingin dicari. Description berisikan diskripsi atau arti atau keterangan dari akun yang telah dipilih. Sedangkan Departement berisikan departemen mana akun yang telah dipilih berada. Jendela kedua berisikan tentang kamus, tentang kamus berisikan mengenai bagaimana kamus tersebut digunakan. Jendela ketiga adalah tentang penulis yang mendiskripsikan siapa penulis kamus. Sedangkan jendela terakhir adalah 
ucapat terima kasih kepada berbagi pihak yang berperan dalam penyusunan kamus. Draft Kamus dirancang berbasis website sehingga apabila nanti ditahun ketiga kamus sudah sempurna maka akan diupload secara online.

Kegiatan akhir dari penelitian adalah ujicoba terbatas. pelaksanaan ujicoba terbatas dilakukan dalam kelompok kecil pada mahasiswa. Hasil dari ujicoba terbatas penggunaan draft software kamus menghasilkan bahwa secara garis besar draft kamus yang dihasikan sangat praktis dalam penggunaan, sangat informative digunakan serta formatnya cukup memberikan kemudahan dalam memperoleh informasi akuntansi perhotelan.

Hasil dari uji coba terbatas menggambarkan bahwa dari sisi penampakan fisik kamus sebanyak $40 \%$ responden puas dengan penampakan kamus, $54 \%$ menyatakan puas namun ada $6 \%$ responden merasa kurang puas. Dari sisi sistematika penyajian sebanyak $30 \%$ responden menyatakan sangat puas, 68\% menyatakan puas dan sisanya $2 \%$ menyatakan kurang puas. Dari sisi format kamus sebanyak $46 \%$ responden merasakan sangat puas dengan format kamus, 52\% menyatakan puas dan 2 persen kurang puas. Sedangkan dari segi kondisi fisik lainnya (gambar,warna,animasi) sebanyak $60 \%$ menyatakan sangat puas dan sisanya $40 \%$ menyatakan puas. Terkait dengan substansi isi kamus sebanyak $66 \%$ responden menyatakan sangat puas, 32 $\%$ menyatakan puas dan sisanya $2 \%$ menyatakan kurang puas. Terkait dengan keandalam materi yang tersaji terutama keseuain dengan standar akuntansi sebanyak $48 \%$ responden menyatakan sangat puas, $46 \%$ menyatakan puas dan $6 \%$ menyatakan kurang puas. Terkait dengan kepraktisan/kemudahan dalam penggunaan sebanyak $60 \%$ menyatakan sangat puas dan sisanya sebanyak $40 \%$ responden menyatakan puas. Sedangkan terakhir terkait kesesuain isi kamus dengan kebutuhan sebanyak $66 \%$ menyatakan sangat puas, $30 \%$ menyatakan puas dan sisanya $4 \%$ menyatakan kurang puas. Bila digeneralisasi maka dapat dikatakan bahwa sebagian besar responden puas dengan pemanfaatan draft kamus akuntansi perhotelan produk penelitian.

Penelitian di tahun kedua (2014) difokuskan pada penyempurnaan Software. Penyempurnaan dilakukan dengan kegiatan desminasi pada 10 hotel berbintang di Bali. Deseminasi dilakukan dengan membagikan Software kepada para praktisi perhotelan di 10 hotel berbintang. Praktisi disini adalah para manager akuntansinya. Setelah itu para pratisi diberikan kuisioner yang berisikan perspektif mereka terhadap Software. Persepsi dari para praktisi diharapkan akan memberikan masukan dalam rangka perbaikan produk software.

Berdasarkan hasil kousioner yang disebar menunjukkan persepsi praktisi akuntansi pada dimensi bukti langsung (tangiable) menunjukkan 70\% responden menyatakan sistematika penyajian software sangat layak, 20\% menyatakan layak dan sisanya sebanyak $10 \%$ menyatakan kurang layak. Dalam hal penyajian format software $50 \%$ menyatakan sangat layak, 30\% menyatakan layak dan sisanya $20 \%$ menyatakan layak. Untuk 
dimensi yaitu ukuran software sebanyak $90 \%$ responden menyatakan sangat layak dan $10 \%$ menyatakan layak. Sedangkan untuk kondisi fisik software secara keseluruhan $80 \%$ menyatakan sangat layak dan sisanya $20 \%$ menyatakan layak.

Persepsi praktisi akuntansi pada dimensi keandalan (reliability) menunjukkan untuk relevansi isi dengan kondisi kerja sebanyak 30\% responden menyatakan sangat layak dan sisanya sebanyak $70 \%$ menyatakan layak. Persepsi praktisi akuntansi pada dimensi daya tanggap (responsiviness) menunjukkan untuk kesesuaian isi materi software dengan kondisi kerja terkini adalah sebanyak $30 \%$ responden menyatakan sangat layak, sebanyak $60 \%$ menyatakan layak dan ada sebanyak $10 \%$ menyatakan kurang layak. Sedangkan daya tanggap software akan pemanfaatan perkembangan teknologi sebanyak $20 \%$ menyatakan sangat layak $80 \%$ yang menyatakan layak. Sedangkan terkait dengan kepraktisan dalam kemudahan memahami isi sebanyak $30 \%$ menyatakan sangat layak, $70 \%$ menyatakan layak.

Persepsi praktisi akuntansi pada dimensi jaminan (assurance) menunjukkan untuk keaslian isi dalam hal belum pernah membaca software sebanyak $80 \%$ responden menyatakan sangat layak, dan sebanyak 20\% menyatakan layak. terkait dengan jaminan kesesuaian dengan Standar Akuntansi Keuangan, $70 \%$ menyatakan sangat layak dan sisanya $30 \%$ menyatakan layak. Sedangkan untuk Indeks Kepuasan Praktisi Akuntansi IKP senilai 90,1 berada pada interval $85 \leq$
IKP $<100$ yang menunjukkan bahwa software sangat layak untuk digunakan.

Berdasarkan hasil penelitian maka yang dapat dibahas dalam penelitian ini diantaranya terkait dengan isu tentang masalah pentingnya penelitian ini dilakukan adalah Hospitality Accounting (Akuntansi Perhotelan) merupakan bidang akuntansi terapan di dunia pariwisata. Dari kacamata akuntansi dunia bisnis pariwisata berbeda dengan dunia usaha lainnya karena merupakan kombinasi antara jasa dan produksi. Hotel merupakan usaha jasa pelayanan atau disebut "hospitality service" yang seluruh atau sebagian bangunan digunakan untuk pelayanan kamar, makanan, minuman serta rekreasi yang dikelola dengan tujuan komersial (Diatmika dan Adi, 2010). Untuk itu hotel sebagai penjual jasa harus dapat menyediakan tiga hal yaitu; fasilitas yang memadai, sumberdaya manusia yang terampil untuk melayani dan pengelolaan yang profesional. Untuk memenuhi hal tersebut dengan sendirinya hotel membutuhkan biaya yang cukup besar dan mahal, baik biaya untuk menyediakan fasilitas maupun biaya untuk pengadaan sumber daya manusia yang melayani berupa gaji yang memadai dan pelatihan-pelatihan yang lebih baik. Semua perhitungan untuk pembiayaan seperti gaji pegawai, transportasi, pemasaran, pembelian semua barang kebutuhan, sampai sekecil-kecilnya harus diperhitungkan secara cermat. Dan untuk mendapatkan data yang cukup akurat serta mengurusi dan mendata keluar masuknya uang maka diperusahaan hotel diperlukan satu departemen khusus yang biasa disebut Accounting Departement atau 
Departemen Akuntansi. Akuntansi Perhotelan merupakan syarat mutlak yang harus dikuasai oleh pegawai yang bekerja di Accounting Departement (Diatmika dan Adi, 2010).

Implementasi akuntansi di dunia perhotelan dapat dilihat dari dua sudut yaitu : (1) dari sudut pemakai akuntansi perhotelan merupakan suatu disiplin yang menyediakan informasi yang diperlukan untuk melaksanakan kegiatan secara efisien dan mengevaluasi kegiatan-kegiatan perhotelan yang digunakan untuk membuat perencanaan yang efektif, pengawasan, pengambilan keputusan oleh manajemen dan pertanggungjawaban pengelolaan pada investor, kreditur, badan pemerintah, donatur dan sebagainya, (2) dari sudut proses kegiatan: akuntansi perhotelan merupakan suatu proses pencatatan, penggolongan, peringkasan, pelaporan dan penganalisaan data keuangan suatu organisasi perhotelan. Sedangkan yang menggunakan informasi akuntansi adalah; (1) Manajemen dalam hal ini manajemen hotel menggunakan laporan keuangan untuk menyusun program kerja, mengevaluasi kemajuan yang dicapai dalam mencapai tujuan, melakukan tindakan tindakan koreksi yang diperlukan dan sebagai salah satu sarana pertanggungjawaban,

Karyawan Hotel memerlukan informasi keuangan untuk mengetahui keadaan keuangan hotel, mengetahui kinerja organisasi serta untuk menyikapi pertanggungjawaban pengelola. Pemilik Hotel memerlukan informasi keuangan untuk mengetahui kinerja hotel, digunakan sebagai dasar perencanaan investasi berikutnya, (4) Pemerintah memerlukan informasi keuangan terutama untuk control dan kebijakan berikutnya, (5) Calon debitur dan debitur memerlukan informasi keuangan sebagai dasar pertimbangan pemberian kredit dan mengevaluasi kredit yang sudah diberikan, dan (6) masyarakat umum lainnya yang dapat digunakan untuk kepentingan penelitian, komparatif dan perkembangan perekonomian.

Untuk dapat mencapai tujuan akuntansi perhotelan diatas maka diperlukan suatu pemahaman Sistem Akuntansi Perhotelan. Sistem akuntansi perhotelan merupakan organisasi formulir, catatan, dan laporan yang dikoordinasi sedemikian rupa untuk menyediakan informasi keuangan yang dibutuhkan oleh manajemen guna memudahkaan pengelolaan hotel. Komponen utama dari sistem akuntansi perhotelan adalah istilah- istilah dari akuntansi perhotelan yang saling terkait dalam pembentukan suatu sistem akuntansi perhotelan. Untuk dapat memahami akuntansi perhotelan maka literature pendukung berupa kamus istilah akuntansi perhotelan sangatlah diperlukan. Terlebih lagi apabila kamus tersebut sudah tertuang dalam bentuk software yang mengakomodasi perkembangan teknologi informasi dan komputer seperti software "Hospitality Accounting Dictionary".

Dari uraian diatas maka nampak jelas bahwa untuk dapat memahami akuntansi perhotelan haruslah terlebih dahulu memahami istilah-istilah akuntansi perhotelan. Pemahaman akuntansi perhotelan dapat dilihat; (1) dari sisi proses pembelajaran di kelas harus dapat memberikan informasi yang maksimal akan kondisi akuntansi riil di dunia perhotelan jelas harus didukung 
oleh literature yang lengkap dan menunjukkan kondisi atau implementasi riil di dunia perhotelan, (2) dari sisi pelaksanaan di dunia kerja para praktisi perhotelan juga memerlukan pemahaman dan informasi yang relevan dalam menyusun laporan keuangan sehingga juga sangat memerlukan litaratur yang dapat memberikan informasi yang tepat dan aplikatif. Dengan ketersediaan litaratur yang tepat dan menggambar kondisi riil di dunia perhotelan maka diharapkan proses pembelajaran yang menghasilkan pemahaman baik bagi siswa maupun kalangan praktisi dapat dicapai dengan hasil yang maksimal.

Terkait dengan temuan penelitian ada beberapa hal yang menjadi temuan penelitian diantaranya (1) belum adanya kamus sejenis terkait dengan akuntansi perhotelan apalagi berbasis teknologi komputer, (2) belum adanya literatur sejenis yang dapat digunakan baik untuk kepentingan pembelajaran maupun untuk kepentingan praktisi riil di dunia kerja, (3) ditemukannya substansi kamus yang berisikan bagan perkiraan untuk masing-masing departemen lengkap dengan deskripsi dan fungsi masingmasing, (4) terwujudnya draft software kamus Akuntansi Perhotelan.

Sebelum menjadi draft software kamus dikelompokkan menjadi 3 kelompok yaitu bagan perkiraan/akun, diskripsi/keterangan dan departemen. Dalam kegiatan ini dhasilkan 1338 perkiraan/akun untuk akuntansi perhotelan dengan deskripsi akun juga sebanyak 1338. Sedangkan departemen yang ada sebanyak 8 departemen yang terdiri atas departemen: adminitration and general, food and beverage, human resources, maketing, other operation dept, POMEC, Rooms dan Telephone and telex. Total jumlah halaman mdraft kamus secara manual adalah sebanyak 168 halaman. Draft software kamus dirancang dalam 4 jendela. Jendela pertama merupakan substansi kamus dimana kamus berfungsi sebagai mesin pencarian tiga dimensi kamus yaitu bisa berupa account, Description dan Departement. Account berisikan berbagai perkiraan akuntansi perhotelan. Pengguna dapat mengklik bagian ini untuk mencari berbagai akun akuntansi perhotelan yang ingin dicari. Description berisikan diskripsi atau arti atau keterangan dari akun yang telah dipilih. Sedangkan Departement berisikan departemen mana akun yang telah dipilih berada. Jendela kedua berisikan tentang kamus, tentang kamus berisikan mengenai bagaimana kamus tersebut digunakan. Jendela ketiga adalah tentang penulis yang mendiskripsikan siapa penulis kamus. Sedangkan jendela terakhir adalah ucapat terima kasih kepada berbagi pihak yang berperan dalam penyusunan kamus. Draft Kamus dirancang berbasis website sehingga apabila nanti ditahun ketiga kamus sudah sempurna maka akan diupload secara online.

Dengan adanya beberapa temuan dalam penelitian ini maka ada beberapa hal yang perlu untuk dijustifikasi diantaranya belum adanya kamus sejenis terkait dengan akuntansi perhotelan apalagi berbasis teknologi komputer memang merupakan suatu kenyataan bahwa belum ada produk sejenis hal ini terjadi karena memang secara komersial produk sejenis memang hanya memiliki pasar terbatas khusus bagi orang yang berkecimpung 
dalam akuntansi perhotelan saja sehingga ini salah satu faktor penyebab belum adanya produk sejenis. Faktor ini pula yang menyebabkan belum adanya literatur sejenis yang dapat digunakan baik untuk kepentingan pembelajaran maupun untuk kepentingan praktisi riil di dunia kerja. Sedangkan dengan terwujudnya draft software kamus Akuntansi Perhotelan diharapkan akan dapat memjembatani sementara kekurang ketersediaan literatur akuntansi perhotelan.

\section{PENUTUP}

Berdasarkan hasil penelitian dan pembahasan maka dapat diperoleh kesimpulan bahwa pelaksanaan penelitian ditahun pertama telah menemukan beberapa temuan diantaranya (1) belum adanya kamus sejenis terkait dengan akuntansi perhotelan apalagi berbasis teknologi komputer, (2) belum adanya literatur sejenis yang dapat digunakan baik untuk kepentingan pembelajaran maupun untuk kepentingan praktisi riil di dunia kerja, (3) ditemukannya substansi kamus yang berisikan bagan perkiraan untuk masing-masing departemen lengkap dengan deskripsi dan fungsi masing-masing, (4) terwujudnya draft software kamus Akuntansi Perhotelan. Draf software akuntansi perhotelan ini sudah diujicobakan secara terbatas dan bila digeneralisasi maka dapat dikatakan bahwa sebagian besar responden puas dengan pemanfaatan draft software kamus akuntansi perhotelan. Mengingat bahwa literatur dalam bentuk software akuntansi perhotelan sangat dibutuhkan baik dalam perkuliahan dikelas maupun aplikasi di dunia kerja maka pengembangan draft software kamus akuntansi perhotelan perlu untuk dilanjutkan menjadi suatu produk kamus final yang sudah sempurna dan perlu diujikan lagi secara lebih luas.

Sedangkan untuk pelaksanaan penelitian secara keseluruhan selama dua tahun telah menghasilkan Software of Hospitality Accounting Dictionary yang sudah diujicobakan dalam proses pembelajaran dengan hasil secara general sebagian peserta kuliah merasa sangat puas dengan pemanfaat software dan para praktisi akuntansi perhotelan juga menunjukkan sangat layak dengan keberadaan Software of Hospitality Accounting Dictionary.

Berdasarkan kesimpulan penelitian maka saran yang dapat diberikan terkait pengembangan perangkat pembelajaran akuntansi khususnya dalam bidang aplikatif seperti akuntansi perhotelan dan akuntansi aplikatif lainnya selayaknya mempertimbangkan aspek-aspek; (1) kondisi riil kebutuhan dalam mata kuliah Akuntansi Perhotelan, (2) kelengkapan informasi yang tersaji, (3) validitas baik dari akademisi maupun praktisi perhotelan, (4) kepraktisan dan keefektifan untuk penggunaan dalam proses belajar mengajar di kelas, (5) kepraktisan dan keefektifan dalam penggunaan di dunia kerja dan (6) up to date terhadap perkembangan teknologi informasi dan komputer.

\section{DAFTAR PUSTAKA}

Adi Yuniarta,. (2008). Pengembangan Problem Based Learning Dengan MYOB Accounting Pada Mata Kuliah Komputer Akuntansi. Jurnal Pendidikan Dan Pengajaran Undiksha Singaraja. 
Adi Yuniarta. (2007). Pemanfaatan Program Komputer Akuntansi terpadu Dalam Rangka Meningkatkan Kualitas Pembelajaran. Jurnal IKA.

Adi Yuniarta. (2009). Analisis Kebutuhan tenaga Profesional Bidang Akuntansi Pada Koperasi. Media Komunikasi FIS Undiksha Singaraja

AL. Haryono Jusup.(2001) Dasar dasar Akuntansi. Jilid 1. Yogyakarta: Bagian Penerbitan STIE YKPN.

AL. Haryono Jusup.(2001). Dasar dasar Akuntansi, Jilid 2. Yogyakarta: Bagian Penerbitan STIE YKPN.

Anis Chariri, Imam Ghozali. (2003). Teori Akuntansi. Edisi Revisi, Semarang : Badan penerbit Universitas Diponegoro

Arens, Alvin A, Randal J. Elder and Mark S. Beasley. (2003). Auditing and Assurance Service an Integrated Approach. Ninth
Edition. New Jersey: Person Education Inc.

Arnyana, (2006), Model- model Pengembangan Perangkat Pembelajaran, Makalah yang disampaikan dalam Lokakaraya Model-model pembelajaran Unit P3AI IKIP Negeri Singaraja

Diatmika, Adi Yuniarta (2010). Pengembangan Kamus Chart of Accounts untuk Mata kuliah Akuntansi Perhotelan. Jurnal Penelitian dan Pengembangan Sains dan Humaniora. Volume 4 No 3

Diatmika, Adi (2011) Pengembangan Kamus Chart of Accounts untuk Mata kuliah Akuntansi Perhotelan. Laporan penelitian : Lemlit Undiksha

Hansen, Mowen. (2004). Management Accounting. Jakarta: Salemba Empat

Hendriksen, Van Breda. (2000). Teori Akunting. Edisi Kelima. Batam: Penerbit Interaksa. 